\title{
Activity of crude extracts from Brazilian cerrado plants against clinically relevant Candida species
}

\author{
Amabel Fernandes Correia 1,2,6, Dâmaris Silveira ${ }^{3}$, Yris Maria Fonseca-Bazzo ${ }^{3}$, Pérola Oliveira Magalhães ${ }^{3}$, \\ Christopher William Fagg ${ }^{4}$, Elton Clementino da Silva ${ }^{4}$, Suelí Maria Gomes ${ }^{5}$, Lenora Gandolfi, ${ }^{1,6}$, \\ Riccardo Pratesi ${ }^{1,6}$ and Yanna Karla de Medeiros Nóbrega ${ }^{1,6,7^{*}}$
}

\begin{abstract}
Background: Medicinal plants have traditionally been used in many parts of the world as alternative medicine. Many extracts and essential oils isolated from plants have disclosed biological activity, justifying the investigation of their potential antimicrobial activity. In this study, the in vitro antifungal activity of six Brazilian Cerrado medicinal plant species were evaluated against clinically relevant Candida species.

Methods: The crude extract plants were evaluated against American Type Culture Collection (ATCC) standard strains of Candida spp. using disk diffusion method and determining the minimum inhibitory concentration (MIC). The chemical study results were confirmed by HPLC method.

Results: All six plant species showed antifungal activity. Among the species studied, Eugenia dysenterica and Pouteria ramiflora showed significant inhibitory activity against $C$. tropicalis at lowest MIC value of 125 and $500 \mathrm{\mu g} /$ disc, respectively. The Eugenia dysenterica also disclosed MIC value of $125 \mu \mathrm{g} /$ disc against C. famata, $250 \mu \mathrm{g} / \mathrm{disc}$ against C. krusei and $500 \mathrm{\mu g} /$ disc against C. guilliermondii and C. parapsilosis. Pouteria torta, Bauhinia rufa, Erythroxylum daphnites and Erythroxylum subrotundum showed activity against the yeast strains with MIC value of $1000 \mathrm{\mu g} /$ disc. The chemical study of the most bioactive extracts of Eugenia dysenterica and Pouteria ramiflora revealed catechin derivatives and flavonoids as main components.

Conclusions: All six evaluated plant species showed good antifungal potential against several Candida strains. However, E. dysenterica and P. ramiflora showed the higher inhibitory effect against the non-albicans Candida species. Our results may contribute to the continuing search of new natural occurring products with antifungal activity.
\end{abstract}

Keywords: Candida spp, Antifungal, Medicinal plants, Crude plant extract

\section{Background}

The genus Candida, that includes about 200 different species, is a common commensal microorganism of the human skin and mucosal surfaces. However, some Candida species are opportunistic pathogens, capable of causing superficial or systemic infections, mostly in

\footnotetext{
* Correspondence: yannanobrega@gmail.com

'Interdisciplinary Laboratory of Biosciences, School of Medicine, Darcy Ribeiro Campus, University of Brasília, CEP 70.900.910 Brasília, DF, Brazil

${ }^{6}$ Immunogenetic and Chronic-degenerative Diseases Laboratory, School of Medicine, Darcy Ribeiro Campus, University of Brasília, CEP 70.900.910 Brasília, DF, Brazil

Full list of author information is available at the end of the article
}

humans, mainly when debilitated or immunocompromised [1]. The systemic infections due to Candida species are severe infections that can cause high morbidity and mortality [2]. The invasive Candida infection represents the most common infection in hospitals worldwide and has an attributable mortality of $35 \%$ to $60 \%$, causing public health and economic impact, because of high healthcare cost and prolonged length of hospitalization [3, 4]. Among the pathogenic species, Candida albicans is the most common cause of invasive fungal infections in hospital settings, although a growing number of new cases from non-Candida albicans 
species have been detected. An even greater disparity occurred with Candida glabrata, which has been identified as the second most common cause of invasive fungal infections in North America and fourth in rank order in Latin America [5]. Candida tropicalis and Candida parapsilosis have shown increased prevalence worldwide, as rarer species such as Candida guilliermondii, Candida pelliculosa, Candida kefyr, Candida rugosa, and Candida famata have [6].

The limited number of antifungal agents presently available for the treatment of fungal infections support the need for more effective and less toxic treatment strategies in view of the progressive increase in the frequency of infections by non-albicans Candida species, the elevated resistance to antifungal drugs, and the relative toxicity of the antifungal drugs currently in use [7]. Besides, selection pressure due to the continuous exposure of the infectious agent to azoles seems to be the main cause behind the development of resistance to fluconazole that has been considered the drug of choice against Candida species. In spite of its fungistatic nature a prolonged use of this drug is not advisable considering the side effects, hence the increased demand for agents from natural resources as they could presumably act in a host friendly manner [8, 9]. Medicinal plants have traditionally been used in many parts of the world as alternative treatments to traditional medicine [10]. Many extracts and essential oils isolated from plants have been shown to exert biological activity justifying the investigation of their potential antimicrobial activity $[11,12]$. Plants of the Cerrado, a tropical highland savanna covering almost 800,000 sq $\mathrm{mi}$ in the Midwestern region of Brazil have been broadly used in popular medicine [13]. This region is characterized by an enormous range of plants that have been the focus of several research reports $[14,15]$ including the screening of several extracts and essential oils with potential anticandidiasis activity $[16,17]$.

In line with these efforts to increasingly exploit the therapeutic potential of plants of this extremely biodiversity rich region in the present study, we tested the crude extracts of the following botanical species: Eugenia dysenterica DC. [Hexachlamys macedoi Legrand), Pouteria ramiflora (Mart.) Radlk, Pouteria torta (Mart.) Radlk, Bauhinia rufa (Bong.) Steud, Erythroxylum subrotundum A. St.-Hil and Erythroxylum daphnites Mart. for their antifungal activity against American Type Culture Collection (ATCC) of Candida species standard strains.

\section{Methods}

\section{Plant material}

Leaves of Eugenia dysenterica DC. (Hexachlamys macedoi Legrand), Pouteria ramiflora (Mart.) Radlk, Pouteria torta (Mart.) Radlk, Bauhinia rufa (Bong.) Steud, Erythroxylum subrotundum A. St.-Hil and Erythroxylum daphnites
Mart. were collected from the Cerrado biome (the Brazilian savanna) in the city of Brasília (Federal District), located in the Midwestern region of Brazil, and its surroundings. Botanical identification was performed by Professors Suelí Maria Gomes and Christopher William Fagg. The voucher herbarium specimens were deposited at the Herbarium of the University of Brasilia (UB) (Table 1). All necessary permits were obtained for the described field studies.

\section{Extraction procedures}

Leaves were dried at room temperature and subsequently powdered in a knife mill (Marconi Laboratory Equipment, Piracicaba SP, Brazil). The ethanol and hexane crude extracts were obtained by the following way: plant material (40 g) was macerated at room temperature for seven days (repeated for three times), first with hexane $(2 \mathrm{~L})$, followed by ethanol $(2 \mathrm{~L})$. After filtration, the solvents were removed under reduced pressure, using rotary evaporator Hei-Vap coupled to vacuum pump model D-91126 (Heidolph Instruments GmbH \& Co KG, Walpersdorfer, Schwabach) and refrigerator model MX07R-20-HD2E (Heidolph Instruments GmbH \& Co KG, Walpersdorfer, Schwabach) to keep the temperatures below $40{ }^{\circ} \mathrm{C}$. The aqueous crude extract was obtained by infusion, using $400 \mathrm{~g}$ of plant material and distilled water $(3 \mathrm{~L})$. After filtration procedure, water was removed by lyophilization using Advantage Plus XL-70 coupled to vacuum pump model 2005SD and air compressor model 1NNE5 (SP Scientific, Warminster, PA, EUA).

\section{Fungal strains}

American Type Culture Collection (ATCC) standard strains of Candida guilliermondii (ATCC 6260), Candida tropicalis (ATCC 28707), Candida parapsilosis (ATCC 22019), Candida albicans (ATCC 90028), Candida glabrata (ATCC 2001), Candida famata (ATCC 62894), and Candida krusei (ATCC 34135) were used to perform the antifungal activity. The strains were kindly provided by the Oswaldo Cruz Foundation (FIOCRUZ) and stored at $-20{ }^{\circ} \mathrm{C}$.

Table 1 List of plant species used in the study

\begin{tabular}{llll}
\hline Plant species & Family & $\begin{array}{l}\text { Extract } \\
\text { solvent }\end{array}$ & $\begin{array}{l}\text { Voucher } \\
\text { specimen }\end{array}$ \\
\hline $\begin{array}{l}\text { Eugenia dysenterica DC } \\
\text { (Hexachlamys macedoi Legrand) }\end{array}$ & Myrtaceae & A & 914 (UB) \\
Pouteria ramiflora (Mart.) Radlk & Sapotaceae & A, E, H & 3671 (UB) \\
Pouteria torta (Mart.) Radlk & Sapotaceae & E,H & 3674 (UB) \\
Bauhinia rufa (Bong.) Steud & Fabaceae & A, E, H & 32144 (UB) \\
Erythroxylum subrotundum A. St.-Hil & Erythroxylaceae & A, E, H & 2194 (UB) \\
Erythroxylum daphnites Mart & Erythroxylaceae & A, E, H & 2193 (UB) \\
\hline
\end{tabular}

Crude extracts from Leaves: $\mathrm{A}$ aqueous, $\mathrm{E}$ ethanolic, $\mathrm{H}$ hexanic 


\section{Screening of antifungal effect}

For the experiment, $1000 \mu \mathrm{g}$ of each extract were dissolved in $1 \mathrm{~mL}$ of the respective solvent (hexane, ethanol and distilled water) yielding final stock solutions with a concentration of $1000 \mu \mathrm{gmL}^{-1}$. Six millimeters filter paper discs were soaked with $10 \mu \mathrm{L}$ of each extract stock solution hexanic, ethanolic and aqueous crude extracts and dried at room temperature. Agar Sabouraud $24 \mathrm{~h}$ cultures $\left(35 \pm 2{ }^{\circ} \mathrm{C}\right)$ of Candida species were used in the preparation of an inoculum diluted in a $0.85 \%$ saline solution, obtaining a fungal suspension equivalent to a 0.5 standard on the McFarland scale $\left(1 \times 10^{6}\right.$ to $5 \times 10^{6}$ cells per $\mathrm{mL}$ ). On Petri dishes the fungal inoculum was spread over the surface of Mueller-Hinton + glucose $(2 \%)+$ methylene blue $\left(0.5 \mu \mathrm{gmL}^{-1}\right)$ agar medium in which discs with the extracts and controls were subsequently deposited. The reading of the zone of inhibition was taken after 24 to $48 \mathrm{~h}$ of incubation at $35 \pm 2{ }^{\circ} \mathrm{C}$ $[18,19]$. Fluconazole $(25 \mu \mathrm{g} /$ disc $)$ was used as positive reference standard and, as negative control filter paper discs with ethanol, distilled water and hexane.

\section{Minimal Inhibitory Concentrations (MIC) test}

Only extracts that disclosed inhibition zone against the different Candida species underwent the MIC evaluation in the disc-diffusion assay, this technique was adapted by Razmavar et al. [19]. The extract stock solution was twofold diluted by serial dilutions resulting in concentrations ranging from 500 to 15.6 $\mu \mathrm{gmL}^{-1}$. After the serial dilutions, $10 \mu \mathrm{L}$ of each dilution was soaked into $6 \mathrm{~mm}$ filter paper discs that were subsequently dried at room temperature. The fungal inoculum was spread over the surface of Mueller-Hinton + glucose $(2 \%)+$ methylene blue $\left(0.5 \mu \mathrm{gmL}^{-1}\right)$ agar and discs were deposited in the culture medium. The plates were incubated at $35 \pm 2{ }^{\circ} \mathrm{C}$ for 24 to $48 \mathrm{~h}$ [19]. The MIC (minimum inhibitory concentration) was defined as the lowest concentration of the tested extracts that was able to inhibit any visible microbial growth [20]. Solvent free extract was used as negative control and Fluconazole $(25 \mu \mathrm{g} / \mathrm{disc})$ was used as positive reference standard.

\section{Apparatus and chromatographic conditions}

The extracts were Analyzed using LaChrom Elite HPLC system (Hitachi, Japan) liquid chromatograph equipped with L2130 pump, L2200 auto-sampler; L2300 column oven was in set at $25{ }^{\circ} \mathrm{C}$. The detector, L2455 DAD (Hitachi, Japan) was set at $280 \mathrm{~nm}$. Separation was performed by Purospher Star reverse phase C18e column $(5 \mu \mathrm{m}, 150 \mathrm{~mm} \times 4.6 \mathrm{~mm}$ i.d.) in combination with an appropriate guard column $(4 \times 4 ; 5 \mu \mathrm{m}$ particle size $)$ (Merck, Germany). The mobile phase was a linear solvent gradient system consisting of phosphoric acid (1\%) (A) and $\mathrm{CH}_{3} \mathrm{CN}$ (B), at a flow rate of $0.6 \mathrm{~mL} / \mathrm{min}$. Data acquisition was performed using EXChrom Elite software (version 3.3.2 SP1, Scientific Software. Inc.). The compounds present in the extract were characterized according to their UV-vis spectra and identified by their retention time in comparison with those of commercial standards (catechin, epicatechin, isoquercitrin myricetin, caffeic acid, chlorogenic acid, ferulic acid, kaempherol, rosmarinic acid, hesperentin, hesperidin, ellagic acid, gallic acid, hyperoside, quercetin, revesratrol, rutin, vitexin and isovitexin) [14].

\section{Results and discussions}

The antifungal activity of crude extracts of Eugenia dysenterica, Pouteria ramiflora, Pouteria torta, Bauhinia rufa, Erythroxylum subrotundum and Erythroxylum daphnites against ATCC standards strains of Candida spp. are shown in Table 2. The ethanol extract of Erythroxylum daphnites and all the hexane extract failed to show any inhibitory activity. However, all aqueous extracts and the remaining five ethanol extracts showed a variable inhibitory activity against one or more species of Candida.

Among all the extracts that were assessed the aqueous extract of Eugenia dysenterica was the most effective. Except for C. albicans and C. glabatra in which no inhibition could be detected, this extract showed significant inhibitory activity against $C$. parapsilosis, C. guilliermondii, C. tropicalis, C. krusei and C. famata, with a zone of inhibition extending from 12 to $15 \mathrm{~mm}$. The ethanolic extract Pouteria ramiflora also showed significant antifungal potential against C. glabrata, C. tropicalis and C. krusei, disclosing a zone of inhibition varying between 10 to $23 \mathrm{~mm}$. Similarly, the ethanol extract of Pouteria torta and the aqueous extract of Erythroxylum subrotundum were effective against three Candida species and showed comparable antifungal activity against C. parapsilosis (10 and $11 \mathrm{~mm})$, C. guilliermondii $(10 \mathrm{~mm})$ and C. glabrata (15 and $30 \mathrm{~mm})$. Two species, C. tropicalis $(12 \mathrm{~mm})$ and C. glabrata $(20 \mathrm{~mm})$ were inhibited by aqueous extract of Pouteria ramiflora while the ethanolic extract of Erythroxylum subrotundum and the aqueous extract of Bauhinia rufa, revealed antifungal activity against $C$. parapsilosis $(10 \mathrm{~mm})$ and $C$. glabrata (20 to $25 \mathrm{~mm}$ ). Finally, the aqueous extract of Erythroxylum daphnites and the ethanolic extract of Bauhinia rufa showed inhibitory effect only against $C$. glabrata (24 and $25 \mathrm{~mm}$ ). In the present study, C. glabrata was the most sensitive specie to the inhibitory activity of the majority of the extracts, whereas $C$. albicans was the most resistant since none of the assessed extracts showed any effect on its growth. The other species of Candida showed variable degrees of resistance and sensitivity to different extracts that were tested. 
Table 2 Antifungal activity of ATCC strains exerted by plant crude extracts by the Embedded Disc Assay

\begin{tabular}{|c|c|c|c|c|c|c|c|c|c|c|c|c|c|c|c|c|c|}
\hline \multirow[t]{3}{*}{ Strain ATCC } & \multirow[t]{3}{*}{ Origin } & \multicolumn{16}{|c|}{ Inhibition Diameter (mm) } \\
\hline & & \multicolumn{5}{|c|}{ Aqueous Extract } & \multicolumn{5}{|c|}{ Ethanolic Extract } & \multicolumn{5}{|c|}{ Hexanic Extract } & \multirow[b]{2}{*}{ Fluconazole $25 \mu \mathrm{g}$} \\
\hline & & E. dysenterica & P. ramiflora & E. subrotundum & E. dapnites & B. rufa & P. ramiffora & P. torta & E. subrotundum & E. dapnites & B. rufa & P. ramiflora & P. torta & E. subrotundum & E. dapnites & B. rufa & \\
\hline C. glabrata (2001) & Feces & & 20 & 30 & 24 & 25 & 23 & 15 & 20 & - & 25 & - & - & & - & - & 40 \\
\hline C. parapsilosis (22019) & Feces & 15 & - & 11 & & 10 & - & 10 & 10 & - & - & - & - & & - & - & 33 \\
\hline C. guilliermondii (6260) & Saliva & 12 & - & 10 & & - & - & 10 & - & & - & & - & & & - & 50 \\
\hline C. tropicalis (28707) & Urine & 12 & 12 & & & & 13 & & - & & & & - & & & - & 30 \\
\hline C. krusei (34135) & Clinical Specimen & 13 & - & - & & - & 10 & & - & - & - & - & - & & - & - & 18 \\
\hline C. famata (62894) & Catheter tip & 12 & & & & & - & & & & & & & & & & 35 \\
\hline C. albicans (90028) & Blood & & & - & - & & & - & - & - & - & - & & - & - & - & 39 \\
\hline
\end{tabular}

(-) Absence of antifungal activity 
Table 3 The Minimum Inhibitory Concentration (MIC) of ATCC strains of Candida spp. exerted by plant crude extracts by the Embedded Disc Assay

\begin{tabular}{|c|c|c|c|c|c|c|c|c|c|c|c|c|c|c|c|c|c|}
\hline \multirow[t]{3}{*}{ ATCC } & \multirow[t]{3}{*}{ Origin } & \multicolumn{15}{|l|}{ CIM ( $\mu \mathrm{g} / \mathrm{disc})$} & \multirow{3}{*}{$\begin{array}{l}\text { Diameter (mm) } \\
\text { Fluconazole } 25 \mu \mathrm{g}\end{array}$} \\
\hline & & \multicolumn{5}{|c|}{ Aqueous Extract } & \multicolumn{5}{|c|}{ Ethanolic Extract } & \multicolumn{5}{|c|}{ Hexanic Extract } & \\
\hline & & E. dysenterica & P. ramiflora & E. subrotundum & E. dapnites & B. rufa & P. ramiflora & P. torta & E. subrotundum & E. dapnites & B. rufa & P. ramiflora & P. torta & E. subrotundum & E. dapnites & B. rufa & \\
\hline C. glabrata (2001) & Feces & - & 1000 & 1000 & 1000 & 1000 & 1000 & 1000 & 1000 & - & 1000 & - & - & - & - & - & 40 \\
\hline $\begin{array}{l}\text { C. parapsilosis } \\
\text { (22019) }\end{array}$ & Feces & 500 & - & 1000 & & 1000 & & 1000 & 1000 & - & & - & & & - & & 33 \\
\hline $\begin{array}{l}\text { C. guilliermondii } \\
(6260)\end{array}$ & Saliva & 500 & - & 1000 & & - & & 1000 & - & - & & - & & & - & - & 50 \\
\hline C. tropicalis (28707) & Urine & 125 & 500 & - & - & - & 500 & - & - & - & - & - & - & - & - & - & 30 \\
\hline C. krusei (34135) & $\begin{array}{l}\text { Clinical } \\
\text { Specimen }\end{array}$ & 250 & - & - & - & - & 1000 & - & - & - & - & - & - & - & - & - & 18 \\
\hline C. famata (62894) & Catheter tip & 125 & & - & - & - & - & - & - & - & - & & - & - & - & - & 35 \\
\hline C. albicans (90028) & Blood & - & - & - & & - & & & - & - & & - & & & - & & 39 \\
\hline
\end{tabular}

(-) Absence of antifungal activity 


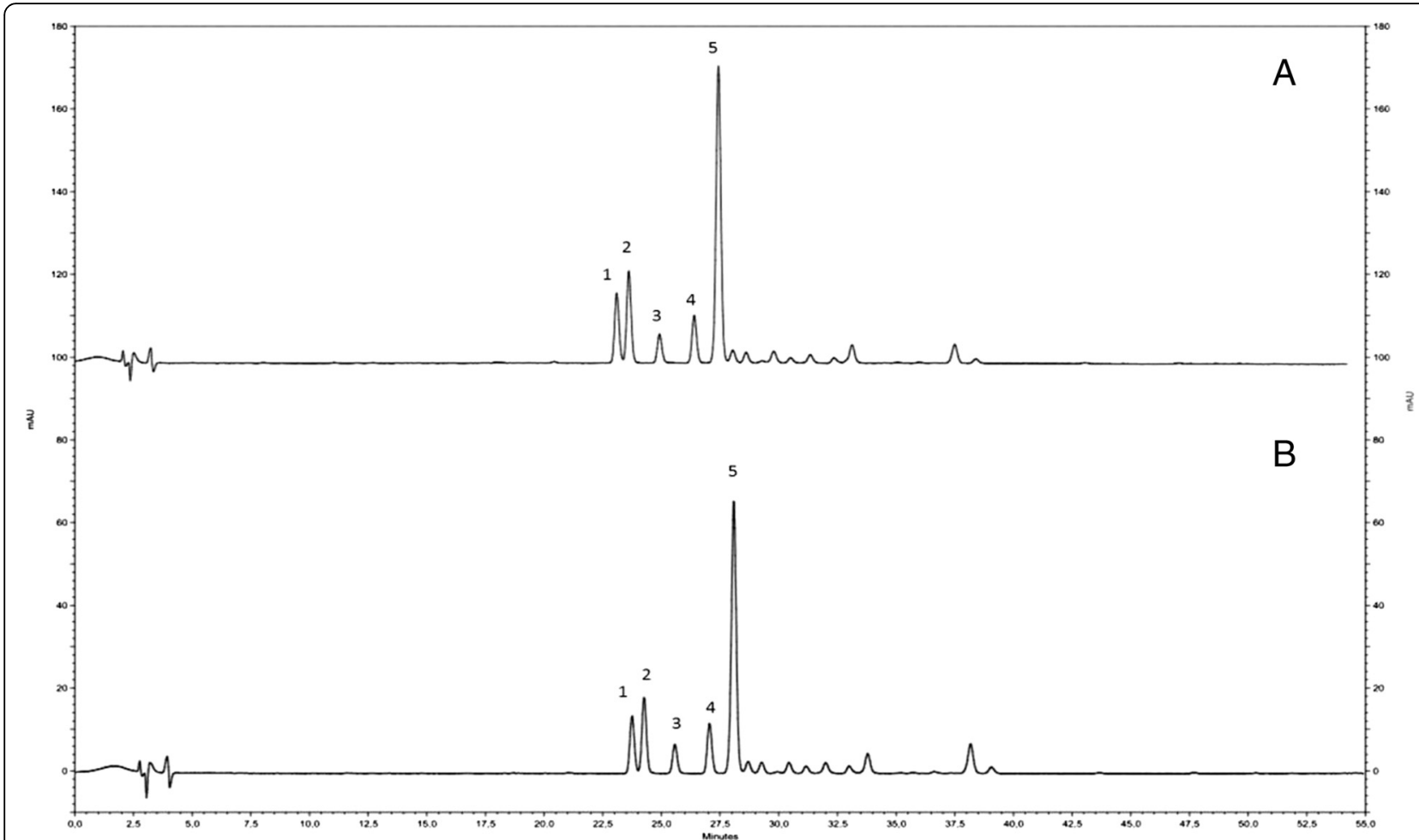

Fig. 1 Chromatography profiles from aqueous and ethanolic leaf extracts from Pouteria ramiflora. a aqueous leaf extract from Pouteria ramiflora and $\mathbf{b}$ ethanolic leaf extract from Pouteria ramiflora

Scarce previous reports exist on the antifungal activity of the medicinal plants hereby described. In support of our results Costa et al. [21] described absence of inhibitory activity of $E$. dysenterica essential oil against $C$. albicans although it showed effectiveness against the pathogenic yeast Cryptococcus. Boleti et al. [22] reported the antifungal potential of $P$. torta extract against different yeasts and filamentous fungi and considered that the action of the pouterin, a lectin-like protein found in its seeds, interacting with cell wall carbohydrates of the fungus, results in an inhibitory effect on the growth. As far as we know antifungal activity of $P$. ramiflora, E. subrotundum, E. daphnites and $B$.

Table 4 Retention time and maximum absorption of chromatographic peaks found in P. ramiflora extracts

\begin{tabular}{|c|c|c|c|}
\hline \multicolumn{2}{|c|}{$\begin{array}{l}\text { Aqueous leaf extract from } \\
\text { P. ramiflora }\end{array}$} & \multicolumn{2}{|c|}{$\begin{array}{l}\text { Alcoholic leaf extract from } \\
\text { P. ramiflora }\end{array}$} \\
\hline Retention Time & Lambda max & Retention Time & Lambda max \\
\hline 23.84 & 265,354 & 23.84 & 263,357 \\
\hline 24.35 & 263,354 & 24.36 & 263,354 \\
\hline 25.65 & 268,354 & 25.66 & 265,358 \\
\hline 27.13 & 265,354 & 27.14 & 264,358 \\
\hline 28.23 & 262,350 & 28.16 & 262,350 \\
\hline
\end{tabular}

rufa has not be previously reported, although some studies have identified the presence of alkaloids and flavonoids in the genus Erythroxylum [23-25] which may partly explain its activity against Candida. Antifungal activity has also been reported for some species Bauhinia [26, 27].

In view of the scarcity of data regarding the antifungal activity against Candida yeasts of the plants tested in the present study and in order to identify and confirm the possible medicinal potential of the extracts that had previously disclosed positive results in an initial screening, i.e. extracts that had exhibited an inhibition zone $\geq 10 \mathrm{~mm}$ against Candida species, we proceeded to the determination of their final minimal inhibitory concentration (MIC).

Table 5 Retention time and maximum absorption of chromatographic peaks found in E. dysenterica extracts

\begin{tabular}{ll}
\hline Aqueous leaf extract from E. dysenterica & \\
\hline Retention Time & Lambda max $(\mathrm{nm})$ \\
\hline 11.573 & 270 \\
11.457 & 280 \\
ND & 300 \\
\hline
\end{tabular}

ND (No Detected) 


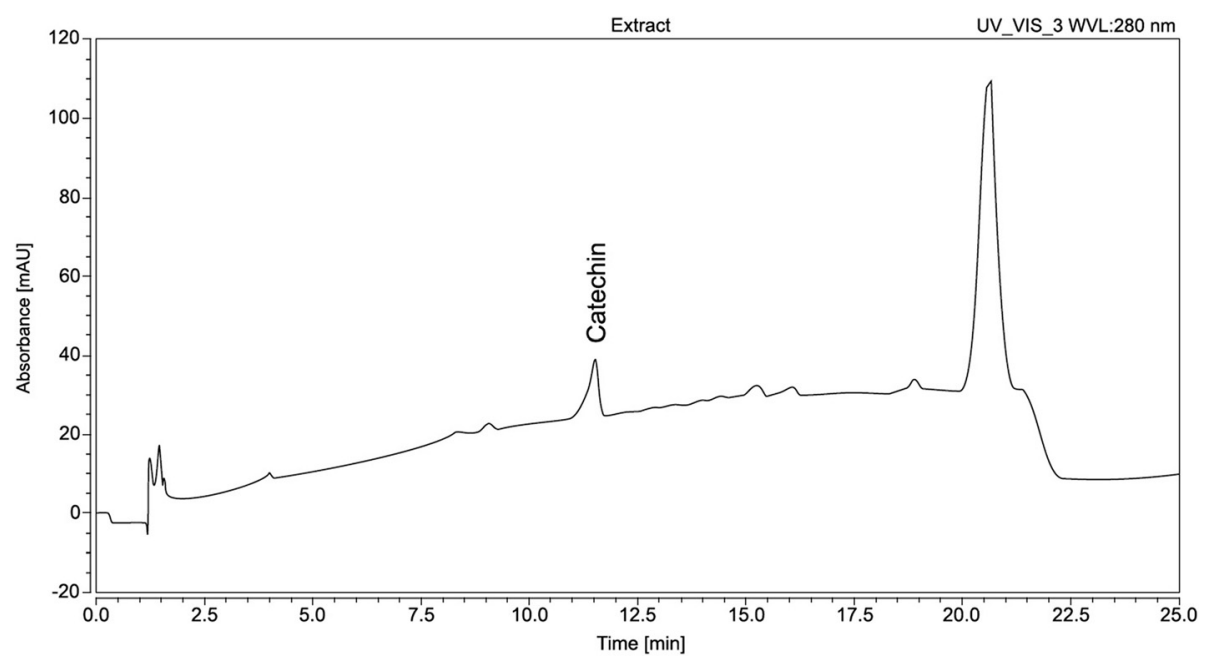

Fig. 2 Chromatography profiles from aqueous leaf extracts from Eugenia dysenterica

The results of MIC values from the diverse plant extracts tested are shown in Table 3. The results confirmed that the aqueous extract of E. dysenterica was the most effective against the different species of Candida. This extract exhibited respectively a MIC $125 \mu \mathrm{g} /$ disc against C. tropicalis and C. famata, a MIC of $250 \mu \mathrm{g} /$ disc against C. krusei and a MIC of $500 \mu \mathrm{g} /$ disc against $C$. parapsilosis and C. guilliermondii. On the other hand, the aqueous and ethanolic extract of $P$. ramiflora showed effectivity against $C$. tropicalis with a MIC of $500 \mu \mathrm{g} /$ disc. A MIC of $1000 \mu \mathrm{g} /$ disc was found on testing the remaining extracts.

In a second step, considering that the lower the MIC of a drug, the greater its effectiveness, the phytochemical composition of $E$. dysenterica and $P$. ramiflora extracts, that had showed a MIC $<1000 \mu \mathrm{g} /$ disc, was determined. The identification of the individual compounds responsible for the antifungal activity was performed by HPLC. The profiles of the aqueous and ethanolic extracts of $P$. ramiflora disclosed a large number of similar compounds with five main peaks (Fig. 1) [14]. The peaks $1-5$ have characteristic UV/Vis spectra of flavonoids, with $\lambda^{\max }$ between 340 and $370 \mathrm{~nm}$ (Table 4). Identification of the peaks by comparison with commercial standards was not possible. Nevertheless, our $P$. ramiflora HPLC results showed similar UV/Vis peaks characteristic of the spectra of flavonoids as those found by Arapitsas [28]. Moreover, the peaks found in both extracts showed maximum absorption around 265 and $354 \mathrm{~nm}$ (Table 4) corroborating with maximum absorption of isorhamnetin derivatives described by Parejo et al. [29]. Flavonoids are the most studied groups of phenolic compounds, comprising molecules with established antifungal properties [30]. The study of compounds isolated from Calotropis procera Ait (Asclepiadaceae), ie the crude flavonoid fraction and flavonols (Quercetin-3-O-rutinoside, Kaempferol-3-Orutinoside, Isorhamnetin-3-O-rutinoside, 5-Hydroxy-3,7dimethoxyflavone-40-O-b-glucopyranoside), showed inhibitory effects of these compounds on $C$. tropicalis moreover against C. albicans [31].

On the other hand, the aqueous extract of $E$. dysenterica showed three main peaks, which have characteristic UV/Vis of catechin derivatives, with maximum absorbance near $280 \mathrm{~nm}$ and no absorption at 320 or $350 \mathrm{~nm}$ (Table 5, Fig. 2) [32]. Alves et al. [33] previously reported antifungal activity against species Candida of cathechin derivatives extracted from flowers of Castanea sativa, Filipendula ulmaria, Rosa micrantha and Cytius multiflorus, and from fresh leaves of Cistus ladanifer. The polyphenols (catechins and theaflavins) present in black tea also showed antifungal activity against species of Candida [34].

\section{Conclusions}

All six evaluated plant species showed good antifungal potential against several Candida strains. E. dysenterica and $P$. ramiflora showed the higher inhibitory effect against the non-albicans Candida species. The chemical analysis of $E$. dysenterica and P. ramiflora extracts disclosed presence of polyphenols (flavonoids and catechins), an important chemical class with antifungal activity. Considering the increasing number of infections by non-albicans Candida species and focusing on their importance for public health, our results may contribute to the continuing search of new natural occurring products with antifungal activity. 


\section{Acknowledgments}

We acknowledge for financial support from The National Council of Technological and Scientific Development (CNPQ), The Brazilian Innovation Agency (FINEP), and Coordination for the Improvement of Higher Education Personnel (CAPES).

\section{Funding}

The National Council of Technological and Scientific Development (CNPQ), The Brazilian Innovation Agency (FINEP), and Coordination for the Improvement of Higher Education Personnel (CAPES)

\section{Availability of data and materials}

Not applicable.

\section{Authors' contributions}

$G L$ have the original idea and made substantial contributions to the conception and design of the study. AFC wrote the study protocol, did the laboratory work and wrote the initial version of the paper. DS prepared the crude extracts of plants. The chromatographic conditions were analyzed using HPLC system were realized by YMF-B for the plants Eugenia dysenterica DC. (Hexachlamys macedoi Legrand), Pouteria ramiflora (Mart.) Radlk, Pouteria torta (Mart.) Radlk and by POM for the plants Bauhinia rufa (Bong.) Steud, Erythroxylum subrotundum A. St.-Hil and Erythroxylum daphnites Mart. The plants were collected by ECdaS, the botanical identification were realized by CWF and voucher herbarium specimens were deposited by SMG. YKdeMN supervised the laboratory work, analyzed laboratory data and analysis and wrote wrote the final version of the methods of paper. RP wrote the final version of the paper and additionally performing the final critical review of the paper. All authors have seen and approved the final version of the paper The authors declare no conflicts of interest and confirm that there was no funding source for this study.

\section{Competing interests}

The authors declare that they have no competing interests.

\section{Consent for publication}

Not applicable.

\section{Ethics approval and consent to participate}

Not applicable.

\section{Author details}

'Interdisciplinary Laboratory of Biosciences, School of Medicine, Darcy Ribeiro Campus, University of Brasília, CEP 70.900.910 Brasília, DF, Brazil. ${ }^{2}$ Central Public Health Laboratory of the District Federal (LACEN-DF), Medical Biology Management, Center of Parasitology and Mycology, CEP 70.830.010 Brasília, DF, Brazil. 'aboratory of Natural Products, Faculty of Health Sciences, Darcy Ribeiro Campus, University of Brasília, CEP 70.900.910 Brasília, DF, Brazil. ${ }^{4}$ School of Pharmacy, Ceilândia Campus, University of Brasília, CEP 72.220.900 Brasília, DF, Brazil. ${ }^{5}$ Department of Botany, Institute of Biological Science, Darcy Ribeiro Campus, University of Brasília, CEP 70.900.910 Brasília, DF, Brazil. ${ }^{6}$ Immunogenetic and Chronic-degenerative Diseases Laboratory, School of Medicine, Darcy Ribeiro Campus, University of Brasília, CEP 70.900.910 Brasília, DF, Brazil. ${ }^{7}$ Department of Pharmaceutical Sciences, School of Health Sciences, Darcy Ribeiro Campus, University of Brasília, CEP 70.900.910 Brasília, DF, Brazil.

Received: 18 September 2015 Accepted: 15 June 2016

\section{Published online: 11 July 2016}

\section{References}

1. Jenkinson HF, Douglas LJ. Interactions between Candida Species and Bacteria en Mixed Infections. In: Polymicrobial Diseases [Internet]. Washington (DC): ASM Press; 2002. Available from: http://www.ncbi.nIm.nib. gov/books/NBK2486

2. Zaoutis TE, Argon J, Chu J, Berlin JA, Walsh TJ, Feudtner C. The epidemiology and attributable outcomes of candidemia in adults and children hospitalized in the United States: A propensity analysis. Clin Infect Dis. 2005:41(9):1232-9.

3. Gudlaugsson O, Gillespie S, Lee K, Berg JV, Hu JF, Messer S, et al. Attributable mortality of nosocomial candidemia, revisited. Clin Infect Dis. 2003;37(9):1172-7.
4. WHO. Antimicrobial resistance: global report on surveillance 2014. Available from: http://www.who.int/drugresistance/documents/surveillancereport/en/.

5. Pfaller MA, Diekema DJ, Gibbs DL, Newell VA, Ellis D, Tullio V, et al. Results from the ARTEMIS DISK Global Antifungal Surveillance Study, 1997 to 2007: a 10.5-Year Analysis of Susceptibilities of Candida Species to Fluconazole and Voriconazole as Determined by CLSI Standardized Disk Diffusion. J Clin Microbiol. 2010;48(4):1366-77.

6. Miceli MH, Diaz JA, Lee SA. Emerging opportunistic yeast infections. Lancet Infect Dis. 2011;11(2):142-51.

7. Spampinato C, Leonardi D. Candida Infections, Causes, Targets, and Resistance Mechanisms: Traditional and Alternative Antifungal Agents. Biomed Res Inter. 2013;2013:204237. doi:10.1155/2013/204237. Epub 2013 Jun. http://www.ncbi.nlm.nih.gov/pmc/articles/PMC3708393/.

8. Sheehan DJ, Hitchcock CA, Sibley CM. Current and emerging azole antifungal agents. Clin Microbiol Rev. 1999:12(1):40-79.

9. Zore GB, Thakre AD, Jadhav S, Karuppayil SM. Terpenoids inhibit Candida albicans growth by affecting membrane integrity and arrest of cell cycle. Phytomedicine. 2011;18(13):1181-90.

10. Palombo EA. Traditional Medicinal Plant Extracts and Natural Products with Activity against Oral Bacteria: Potential Application in the Prevention and Treatment of Oral Diseases. Evid-Based Complement Altern Med. 2011; 2011:680354. doi:10.1093/ecam/nep067. Epub 2011 Jan 12. http://www.ncbi. nlm.nih.gov/pmc/articles/PMC3145422/.

11. Furletti VF, Teixeira IP, Obando-Pereda G, Mardegan RC, Sartoratto A, Figueira GM, et al. Action of Coriandrum sativum L. Essential Oil upon Oral Candida albicans Biofilm Formation. Evid-Based Complement Altern Med. 2011:1-9. 2011:985832. doi:10.1155/2011/985832. Epub 2011 May 21. http://www.ncbi.n/m.nih.gov/pmc/articles/PMC3108195/.

12. Pietrella D'Angiolella L, Vavala E, Rachini A, Mondello F, Ragno R, et al. Beneficial effect of Mentha suaveolens essential oil in the treatment of vaginal candidiasis assessed by real-time monitoring of infection. BMC Complement Altern Med. 2011;11:18. doi:10.1186/1472-6882-11-18. http://www.ncbi.nlm.nih.gov/pmc/articles/PMC3056850/.

13. Septimio LR. Fitoterapia baseada em ervas medicinais do Cerrado. Brasília: SIPE. Ministério da Agricultura; 1994.

14. Souza PM, Elias ST, Simeoni LA, de Paula JE, Gomes SM, Silva Guerra EN, et al. Plants from Brazilian Cerrado with Potent Tyrosinase Inhibitory Activity. Plos One. 2012;7(11):e48589. doi:10.1371/journal.pone.0048589. Epub 2012 Nov 16. http://www.ncbi.nlm.nih.gov/pmc/articles/PMC3500240/.

15. Zambuzzi-Carvalho PF, Tomazett PK, Santos SC, Ferri PH, Borges CL, Martins WS, et al. Transcriptional profile of Paracoccidioides induced by oenothein B, a potential antifungal agent from the Brazilian Cerrado plant Eugenia uniflora. BMC Microbiol. 2013;13:227. doi:10.1186/1471-2180-13-227. http:/www.ncbi.nlm. nih.gov/pmc/articles/PMC3852496/

16. de Silva Melo F, de Paula JE, Espindola LS. Evaluation of the antifungal potential of Brazilian Cerrado medicinal plants. Mycoses. 2009;52(6):511-7.

17. Albernaz $L C$, de Paula JE, Sierra Romero GA, Rodrigues Silva MR, Grellier $P$, Mambu $L$, et al. Investigation of plant extracts in traditional medicine of the Brazilian Cerrado against protozoans and yeasts. J Ethnopharmacol. 2010;131(1):116-21.

18. CLSI. Method for Antifungal Disk Diffusion Susceptibility Testing of Yeasts: Approved Guideline. In: Sheehan DJ BS, Pfaller MA, Warnock DW, Rex JH, Chaturvedi V, Espinel-Ingroff A, Ghannoum MA, Moore LS, Odds FC, Rinaldi MG, Walsh TJ. Waine, Pensilvânia - USA; 2004

19. Razmavar S, Abdulla MA, Ismail SB, Hassandarvish P. Antibacterial Activity of Leaf Extracts of Baeckea frutescens against Methicillin-Resistant Staphylococcus aureus. Biomed Res Int. 2014; 2014:521287. doi:10.1155/ 2014/521287. Epub 2014 Jun 16. http://www.ncbi.nlm.nih.gov/pmc/articles/ PMC4083884/.

20. Dzomba P, Muchanyereyi N. Potential antimicrobial plant extract based therapeutics from Temnocalyx obovatus roots. Eur J Medicinal Plants. 2012;2(3):209-15.

21. Costa TR, Fernandes OFL, Santos SC, Oliveira CMA, Liao LM, Ferri PH, et al. Antifungal activity of volatile constituents of Eugenia dysenterica leaf oil. J Ethnopharmacol. 2000;72(1-2):111-7.

22. Boleti APDA, Freire MDGM, Coelho MB, Da Silva W, Baldasso PA, Gomes VM, et al. Insecticidal and antifungal activity of a protein from Pouteria torta seeds with lectin-like properties. J Agric Food Chem. 2007:55(7):2653-8.

23. Johnson EL, Schmidt WF. Flavonoids as chemotaxonomic markers for Erythroxylum australe. Zeitschrift Fur Naturforschung C-a Journal of Biosciences. 2004;59(11-12):769-76. 
24. Brock A, Bieri S, Christen P, Drager B. Calystegines in wild and cultivated Erythroxylum species. Phytochemistry. 2005;66(11):1231-40.

25. Bieri S, Brachet A, Veuthey JL, Christen P. Cocaine distribution in wild Erythroxylum species. J Ethnopharmacol. 2006;103(3):439-47.

26. Achenbach H, Stocker M, Constenla MA. Flavonoid and other constituents of Bauhinia manca. Phytochemistry. 1988;27(6):1835-41.

27. Maillard MP, Recioiglesias MC, Saadou M, Stoecklievans H, Hostettmann K. Novel antifungal tetracyclic compounds from Bauhinia rufescens LAM. Helv Chim Acta. 1991;74(4):791-9.

28. Arapitsas P. Identification and quantification of polyphenolic compounds from okra seeds and skins. Food Chem. 2008;110(4):1041-5.

29. Parejo I, Jauregui O, Sanchez-Rabaneda F, Viladomat F, Bastida J, Codina C. Separation and characterization of phenolic compounds in fennel (Foeniculum vulgare) using liquid chromatography-negative electrospray ionization tandem mass spectrometry. J Agric Food Chem. 2004:52(12):3679-87.

30. Martins NBL, Henriques M, Silva S. Activity of phenolic compounds from plant origin against Candida. Ind Crop Prod. 2015;74:648-70.

31. Nenaah G. Antimicrobial activity of Calotropis procera Ait. (Asclepiadaceae) and isolation of four flavonoid glycosides as the active constituents. World J Microbiol Biotechnol. 2013;29(7):1255-62.

32. Zorzin FM, Silva SMM, Freitas MM, Coppini RPA, Souza PM, Silveira D, Fonseca, YM, Simeoni, LA, Homem-de-Mello M, Magalhães, PO. Validation of the analytical method by hplc for determination of catechin in Eugenia dysenterica DC. Dry Aqueous Extract: A Brazilian Savannah Native Plant. 2015;2:100-7.

33. Alves CT, Ferreira ICFR, Barros L, Silva S, Azeredo J, Henriques M. Antifungal activity of phenolic compounds identified in flowers from North Eastern Portugal against Candida species. Future Microbiol. 2014;9(2):139-46.

34. Sitheeque MAM, Panagoda GJ, Yau J, Amarakoon AMT, Udagama URN, Samaranayake LP. Antifungal Activity of Black Tea Polyphenols (Catechins and Theaflavins) against Candida Species. Chemotherapy. 2009;55(3):189-96.

\section{Submit your next manuscript to BioMed Central} and we will help you at every step:

- We accept pre-submission inquiries

- Our selector tool helps you to find the most relevant journal

- We provide round the clock customer support

- Convenient online submission

- Thorough peer review

- Inclusion in PubMed and all major indexing services

- Maximum visibility for your research

Submit your manuscript at www.biomedcentral.com/submit

) Biomed Central 